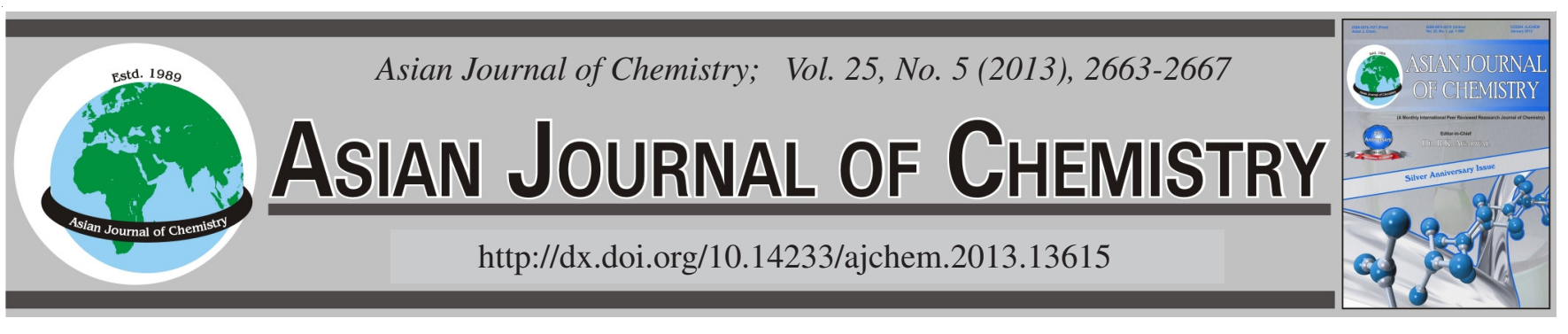

\title{
Quantum Chemistry Based Quantitative Structure-Activity Relationship Prediction Setting for Toxicity of 4-Imidazolyl-1,4-Dihydropyridines as Calcium Channel Blockers
}

\author{
SAAdat VAhdani ${ }^{1}$, Mohsen SAREM ${ }^{2}$ and Farzin HadizadeH ${ }^{3, *}$
}

${ }^{1}$ Department of Chemistry, Islamic Azad University-North Tehran Branch, Tehran, Iran

${ }^{2}$ Department of Chemistry, Payame Nour University, Mashhad, Iran

${ }^{3}$ Biotechnology Research Center, School of Pharmacy, Mashhad University of Medical Sciences, Mashhad, Iran

*Corresponding author: Fax: +98 511 8823251; Tel: +98 511 7112420; E-mail: hadizadehf@mums.ac.ir

(Received: 17 February 2012;

Accepted: 19 November 2012)

AJC-12424

The usefulness of the quantum chemical descriptors, calculated at the level of the DFT theory using 6-31 $\mathrm{G}$ (d,p) basis set for quantitative
structure-activity relationship study of 4 -imidazolyl-1,4-dihydropyridines as calcium channel blockers was examined. A dataset set of
thirty six 1,4-dihydropyridines constitute a group of small organic compounds. Several types of descriptors, including electrotopological,
structural, thermodynamics and quantum chemical, were used to derive a quantitative relationship between L-type calcium channel
blocking activity and structural properties. Multiple linear regressions (MLR) were employed to model the relationships between molecular
descriptors and biological activity of molecules using stepwise method and genetic algorithm as variable selection tools. A multi-parametric
equation containing maximum five descriptors at AM1 method with good statistical qualities $\left(\mathrm{R}_{\text {train }}^{2}=0.860, \mathrm{~F}_{\text {train }}=28.265, \mathrm{Q}^{2}{ }_{\text {LOo }}=0.802\right.$,
$\mathrm{R}^{2}$ adj $\left.=0.829, \mathrm{Q}^{2}{ }_{\text {LGO }}=0.792, \mathrm{Q}^{2}{ }_{\text {BooT }}=0.796\right)$ was obtained by multiple linear regression using stepwise method. The accuracy of the
proposed MLR model was illustrated using the following evaluation techniques: cross-validation and Y-randomization.

Key Words: Quantitative structure-activity relationship, Dihydropyridines, Multiple linear regression, Genetic algorithm, pIC s0 $_{\text {. }}$

\section{INTRODUCTION}

Voltage-gated calcium channels are transmembrane proteins, which upon membrane depolarization, allow selective $\mathrm{Ca}^{2+}$ permeation in excitable cells. Voltage-gated calcium channels are heteromeric proteins consisting of the pore forming a1 subunit, disulfide-linked transmembrane complex of a 2 and $\mathrm{d}$ subunits, intracellular b subunit and an a subunit characteristic for skeletal muscle $\mathrm{Ca}^{2+}$ channels ${ }^{1}$. Variability of regularity subunits distinguishes the tissue-specific calcium channel types ${ }^{2} \mathrm{~L}, \mathrm{~N}, \mathrm{~T}, \mathrm{P}, \mathrm{Q}$ and R. L-type $\mathrm{Ca}^{2+}$ channels are sensitive to numerous agonist and antagonist drugs that modulate the $\mathrm{Ca}^{2+}$ flow. Dihydropyridines include both blocker and activators of $\mathrm{LCCs}^{3}$. As their introduction of calcium channel blockers by Fleckenstein ${ }^{4}$, these compounds have found to have special significance in the therapy of hypertension, angina pectoris and cardiovascular disease ${ }^{5}$. Among the classes of calcium channel blockers, dihydropyridines derivatives are widely used. A quantitative structure-activity relationship study indicated that the potency of nifedipine analogs was dependent upon lipophilicity and electronic term and separate terms for each position on the aromatic ring. Change in the substitution pattern at the C-3, C-4, C-5 positions of nifedipine alter potency ${ }^{6}$, tissue selectivity ${ }^{7,8}$ and conformation of the 1,4-dihydropyridine ring 9 . Our previous studies suggested that heterocyclic substituent like 1-substituted- alkylthioimidazol-5-yl as bioisosteric replacement of nitrophenyl group at C-4 gave active compounds with potent calcium antagonist activity ${ }^{10-13}$. Quantitative structure-activity relationship analysis is an effective method in research into rational drug design and the mechanism of drug actions. In addition, it is useful in areas like the design of virtual compound libraries and the computational-chemical optimization of compounds. Quantitative structure-activity relationship studies can express the biological activities of compounds as a function of their various structural parameters and also describes how the variation in biological activity depends on changes in the chemical structure ${ }^{14}$. Quantitative structure-activity relationship models, mathematical equations relating chemical structure to their biological activity, give information that is useful for drug design and medicinal chemistry ${ }^{15-17}$. A successful quantitative structure-activity relationship model is not only constructed to correctly estimate the numerical value of the property or biological activity, but also to give a deeper understanding of what structural features are important for the observed activity. A major step in constructing the quantitative structure-activity relationship models is finding 
one or more molecular descriptors that represent variation in the structural property of the molecules by a number. Nowadays, a wide variety of descriptors have been used in quantitative structure-activity relationship analysis ${ }^{18-20}$. Recent progress in computational hardware and the development of efficient algorithms have assisted the routine development of molecular quantum chemical calculations. Quantum chemical descriptors offer an attractive alternative to traditional quantitative structureactivity relationship molecular descriptors by expressing a more accurate and detailed description of the electronic and geometric molecular properties and the interaction between them ${ }^{21}$. Recently, Karelson et $a l .{ }^{22}$ reported a comprehensive review on these types of descriptors. Thanikaivelan et al..$^{23}$ defined some new quantum chemical descriptors, including hardness, softness, electronegativity and electrophilicity and used them for a quantitative structure-activity relationship study of alkanes. In a quantitative structure-activity relationship study the model must be validated for its predictive value before it can be used to predict the response of additional chemicals. Validating quantitative structure-activity relationship with external data (i.e. data not used in the model development), although demanding, is the best method for validation. Finally, the accuracy of the proposed model was illustrated using the following: leave one out, cross-validations and Y-randomization techniques.

TABLE-1

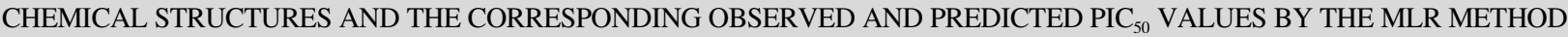<smiles>[R6]c1ncc(C2C(C(=O)O)=C(C)N([2H])C(C)=C2C(=O)O)n1C</smiles>

\begin{tabular}{|c|c|c|c|c|c|c|c|}
\hline No. & $\mathrm{R}_{1}$ & $\mathrm{R}_{2}$ & $\mathrm{R}_{3}$ & $\mathrm{R}_{4}$ & $\mathrm{pIC}_{50}$ exp. & Pred. & Ref. \\
\hline 1 & $\mathrm{CH}_{3}$ & $\mathrm{CH}_{3}$ & $\mathrm{CH}_{3}$ & $\mathrm{SO}_{2} \mathrm{CH}_{3}$ & 0.86027 & 0.625669 & 9 \\
\hline 2 & $\mathrm{C}_{2} \mathrm{H}_{5}$ & $\mathrm{C}_{2} \mathrm{H}_{5}$ & $\mathrm{CH}_{3}$ & $\mathrm{SO}_{2} \mathrm{CH}_{3}$ & 0.789347 & 0.999082 & 9 \\
\hline 3 & $n$-Pr & $n$-Pr & $\mathrm{CH}_{3}$ & $\mathrm{SO}_{2} \mathrm{CH}_{3}$ & 0.574877 & 0.84819 & 9 \\
\hline 4 & $n$-Bu & $n-\mathrm{Bu}$ & $\mathrm{CH}_{3}$ & $\mathrm{SO}_{2} \mathrm{CH}_{3}$ & 0.667086 & 0.792223 & 9 \\
\hline 5 & $n$-pentyl & $n$-pentyl & $\mathrm{CH}_{3}$ & $\mathrm{SO}_{2} \mathrm{CH}_{3}$ & 0.875205 & 0.7196 & 9 \\
\hline 6 & Isobutyl & isobutyl & $\mathrm{CH}_{3}$ & $\mathrm{SO}_{2} \mathrm{CH}_{3}$ & 0.723134 & 0.850389 & 9 \\
\hline 7 & $t$-butyl & $t$-butyl & $\mathrm{CH}_{3}$ & $\mathrm{SO}_{2} \mathrm{CH}_{3}$ & 0.85661 & 0.668108 & 9 \\
\hline 8 & $\mathrm{CH}_{3}$ & $\mathrm{CH}_{3}$ & 4- $\mathrm{FC}_{6} \mathrm{H}_{4} \mathrm{CH}_{2}$ & $\mathrm{SCH}_{3}$ & 1.095585 & 0.858158 & 11 \\
\hline 9 & $\mathrm{CH}_{3}$ & $\mathrm{CH}_{3}$ & $\mathrm{C}_{6} \mathrm{H}_{5} \mathrm{CH}_{2}$ & $\mathrm{SCH}_{3}$ & 0.461588 & 0.911245 & 10 \\
\hline 10 & $\mathrm{C}_{2} \mathrm{H}_{5}$ & $\mathrm{C}_{2} \mathrm{H}_{5}$ & 4- $\mathrm{FC}_{6} \mathrm{H}_{4} \mathrm{CH}_{2}$ & $\mathrm{SCH}_{3}$ & 1.020177 & 0.677142 & 11 \\
\hline 11 & $\mathrm{CH}_{3}$ & $\mathrm{CH}_{3}$ & $\mathrm{C}_{6} \mathrm{H}_{5} \mathrm{CH}_{2}$ & $\mathrm{SC}_{2} \mathrm{H}_{5}$ & 0.518944 & 0.574097 & 10 \\
\hline 12 & $\mathrm{CH}_{3}$ & $\mathrm{CH}_{3}$ & $4-\mathrm{FC}_{6} \mathrm{H}_{4} \mathrm{CH}_{2}$ & $\mathrm{SC}_{2} \mathrm{H}_{5}$ & 1.046083 & 0.80603 & 11 \\
\hline 13 & $\mathrm{C}_{2} \mathrm{H}_{5}$ & $\mathrm{C}_{2} \mathrm{H}_{5}$ & $\mathrm{C}_{6} \mathrm{H}_{5} \mathrm{CH}_{2}$ & $\mathrm{SC}_{2} \mathrm{H}_{5}$ & 0.41345 & 0.860786 & 10 \\
\hline 14 & $\mathrm{C}_{2} \mathrm{H}_{5}$ & $\mathrm{C}_{2} \mathrm{H}_{5}$ & $\mathrm{C}_{6} \mathrm{H}_{5} \mathrm{CH}_{2}$ & $\mathrm{SCH}_{3}$ & 1.00993 & 0.609399 & 10 \\
\hline 15 & $\mathrm{CH}_{3}$ & $\mathrm{CH}_{3}$ & $2-\mathrm{ClC}_{6} \mathrm{H}_{4} \mathrm{CH}_{2}$ & $\mathrm{SCH}_{3}$ & 1.01749 & 0.666391 & 11 \\
\hline 16 & $\mathrm{C}_{2} \mathrm{H}_{5}$ & $\mathrm{C}_{2} \mathrm{H}_{5}$ & $2-\mathrm{ClC}_{6} \mathrm{H}_{4} \mathrm{CH}_{2}$ & $\mathrm{SCH}_{3}$ & 1.012685 & 0.618935 & 11 \\
\hline 17 & $\mathrm{CH}_{3}$ & $\mathrm{CH}_{3}$ & $2-\mathrm{ClC}_{6} \mathrm{H}_{4} \mathrm{CH}_{2}$ & $\mathrm{SC}_{2} \mathrm{H}_{5}$ & 1.00088 & 0.600928 & 11 \\
\hline 18 & $\mathrm{C}_{2} \mathrm{H}_{5}$ & $\mathrm{C}_{2} \mathrm{H}_{5}$ & $2-\mathrm{ClC}_{6} \mathrm{H}_{4} \mathrm{CH}_{2}$ & $\mathrm{SC}_{2} \mathrm{H}_{5}$ & 0.858992 & 0.5666 & 11 \\
\hline 19 & $\mathrm{CH}_{3}$ & $\mathrm{C}_{2} \mathrm{H}_{5}$ & $\mathrm{CH}_{3}$ & $\mathrm{SO}_{2} \mathrm{CH}_{3}$ & 0.600871 & 0.484545 & 9 \\
\hline 20 & $\mathrm{CH}_{3}$ & $n$-pr & $\mathrm{CH}_{3}$ & $\mathrm{SO}_{2} \mathrm{CH}_{3}$ & 0.537459 & 0.576469 & 9 \\
\hline 21 & $\mathrm{C}_{2} \mathrm{H}_{5}$ & n-pr & $\mathrm{CH}_{3}$ & $\mathrm{SO}_{2} \mathrm{CH}_{3}$ & 0.550631 & 1.054337 & 9 \\
\hline 22 & $\mathrm{CH}_{3}$ & i-Pr & $\mathrm{CH}_{3}$ & $\mathrm{SO}_{2} \mathrm{CH}_{3}$ & 0.567289 & 0.859426 & 9 \\
\hline 23 & $\mathrm{CH}_{3}$ & $n-\mathrm{Bu}$ & $\mathrm{CH}_{3}$ & $\mathrm{SO}_{2} \mathrm{CH}_{3}$ & 0.590333 & 0.836931 & 9 \\
\hline 24 & $\mathrm{C}_{2} \mathrm{H}_{5}$ & $n$-Bu & $\mathrm{CH}_{3}$ & $\mathrm{SO}_{2} \mathrm{CH}_{3}$ & 0.619669 & 0.660014 & 9 \\
\hline 25 & $\mathrm{CH}_{3}$ & tert-Bu & $\mathrm{CH}_{3}$ & $\mathrm{SO}_{2} \mathrm{CH}_{3}$ & 0.55005 & 0.673428 & 9 \\
\hline 26 & $\mathrm{C}_{2} \mathrm{H}_{5}$ & tert-Bu & $\mathrm{CH}_{3}$ & $\mathrm{SO}_{2} \mathrm{CH}_{3}$ & 0.570664 & 0.678077 & 9 \\
\hline 27 & $\mathrm{CH}_{3}$ & iso-bu & $\mathrm{CH}_{3}$ & $\mathrm{SO}_{2} \mathrm{CH}_{3}$ & 0.643257 & 0.520971 & 9 \\
\hline 28 & $\mathrm{C}_{2} \mathrm{H}_{5}$ & iso-bu & $\mathrm{CH}_{3}$ & $\mathrm{SO}_{2} \mathrm{CH}_{3}$ & 0.722763 & 0.677142 & 9 \\
\hline 29 & $\mathrm{CH}_{3}$ & $\mathrm{CH}_{2} \mathrm{C}_{6} \mathrm{H}_{5}$ & $\mathrm{CH}_{3}$ & $\mathrm{SO}_{2} \mathrm{CH}_{3}$ & 0.905541 & 0.858158 & 9 \\
\hline 30 & $\mathrm{C}_{2} \mathrm{H}_{5}$ & $\mathrm{CH}_{2} \mathrm{C}_{6} \mathrm{H}_{5}$ & $\mathrm{CH}_{3}$ & $\mathrm{SO}_{2} \mathrm{CH}_{3}$ & 0.72203 & 0.856488 & 9 \\
\hline 31 & $\mathrm{CH}_{3}$ & $\mathrm{CH}_{2} \mathrm{CH}_{2} \mathrm{C}_{6} \mathrm{H}_{5}$ & $\mathrm{CH}_{3}$ & $\mathrm{SO}_{2} \mathrm{CH}_{3}$ & 1.017519 & 0.520971 & 9 \\
\hline 32 & $\mathrm{C}_{2} \mathrm{H}_{5}$ & $\mathrm{CH}_{2} \mathrm{CH}_{2} \mathrm{C}_{6} \mathrm{H}_{5}$ & $\mathrm{CH}_{3}$ & $\mathrm{SO}_{2} \mathrm{CH}_{3}$ & 0.799125 & 0.997021 & 9 \\
\hline 33 & $\mathrm{CH}_{3}$ & Cyclohexyl & $\mathrm{CH}_{3}$ & $\mathrm{SO}_{2} \mathrm{CH}_{3}$ & 0.611643 & 1.077719 & 9 \\
\hline 34 & $\mathrm{C}_{2} \mathrm{H}_{5}$ & Cyclohexyl & $\mathrm{CH}_{3}$ & $\mathrm{SO}_{2} \mathrm{CH}_{3}$ & 0.587993 & 0.879013 & 9 \\
\hline 35 & $\mathrm{CH}_{3}$ & CyclohexylCH $_{2}$ & $\mathrm{CH}_{3}$ & $\mathrm{SO}_{2} \mathrm{CH}_{3}$ & 0.661675 & 0.663886 & 9 \\
\hline 36 & $\mathrm{C}_{2} \mathrm{H}_{5}$ & CyclohexylCH $_{2}$ & $\mathrm{CH}_{3}$ & $\mathrm{SO}_{2} \mathrm{CH}_{3}$ & 0.676576 & 0.815375 & 9 \\
\hline
\end{tabular}




\section{EXPERIMENTAL}

Data set: In this study, the data set of 1, 4-dihydropyridines constitute a group of small organic compounds are based on a core pyridine structure, which can both block and enhance calcium currents ${ }^{9-11}$. The inhibitory activity values are expressed as the half maximal inhibitory concentration $\left(\mathrm{IC}_{50}\right)$. The chemical structures and activity data for the complete set of compounds are presented in Table- 1 . The activity data [ $\mathrm{IC}_{50}$ $(\mu \mathrm{M})]$ was converted to the logarithmic scale $\mathrm{pIC}_{50}\left[-\log \mathrm{IC}_{50}\right.$ (M)] and then used for the subsequent quantitative structureactivity relationship analyses as the response variables. The data set was randomly divided into two subsets: the training set containing 29 compounds ( $80 \%$ ) and the test set containing 7 compounds $(20 \%)$. The training set was used to build a regression model and the test set was used to evaluate the predictive ability of the model obtained.

Quantum chemical calculations: The molecular structures of all the 1,4-dihydropyridines derivatives were built with Hyperchem (Version 7, Hyper Cube Inc.). Gasphase full geometry optimization for the investigated molecules was carried out with the Gaussian 98 series of programs ${ }^{24}$. The structures were optimized with DFT method at the hybrid functional $B_{3}$ LYP (BeckeKs three-parameter ${ }^{25}$ functional employing the Lee, Yang and Parr correlation functional ${ }^{26}$ and the medium-size basis set 6-31 + G (d, p) level. No molecular symmetry constraint was applied; rather full optimization of all bond lengths and angles was carried out. Local charge (LC) calculated according to Mulliken population analysis (MPA) ${ }^{27}$, natural population analysis (NPA) $)^{28}$ and electrostatic potential $(\mathrm{EP})^{29}$ at each atom, highest occupied molecular orbital (HOMO) and lowest unoccupied molecular orbital (LUMO) energies, difference between LUMO and HOMO orbital energies, molecular dipole moment (MDP), molecular polarizability (MP), molecular quadrupole moment (MQM) and molecular volume were calculated by Gaussian 98. The molecular modeling system Hyperchem software was further employed to calculate the following parameters from the energy minimized structures: molecular surface area (MSA), molar refractivity (MR) and hydration energy (HE). Quantum chemical indices of hardness $(\mathrm{h})$, softness $(\mathrm{S})$, electronegativity (c) and electrophilicity (w) were calculated according to the method proposed by Thanikaivelan et al. $n$-Octanol-water partition coefficient $(\log \mathrm{P})$ values were obtained with ACD/ labs computer program ${ }^{30}$. A brief description of the descriptors used in study is represented in Table- 2 .

\section{RESULTS AND DISCUSSION}

Data processing and modeling: The MLR analysis was employed to derive the quantitative structure-activity relationship models for different 1,4-dihydropyridines derivatives. MLR and correlation analyses were carried out by the statistics software SPSS 13.0 version. Before any MLR analysis, the correlation between the selected descriptors was examined (Table-3) and collinear descriptors $(r>0.90)$ were determined. Among these descriptors one of them, which had higher correlation with the dependent variable, was retained and the others were removed from the descriptor data matrix. The remaining descriptors were used to construct the MLR model, in accordance with the stepwise and GA selection methods.
TABLE-2

CALCULATED DESCRIPTORS USED IN THIS STUDY

\begin{tabular}{|c|c|c|}
\hline Descriptors & Symbol & Abbreviation \\
\hline \multirow{6}{*}{$\begin{array}{l}\text { Quantum } \\
\text { chemical } \\
\text { descriptors }\end{array}$} & Molecular dipole moment & MDP \\
\hline & Molecular polarizability & MP \\
\hline & Natural population analysis & NPA \\
\hline & Electrostatic potential & EP \\
\hline & Highest occupied molecular orbital & HOMO \\
\hline & Lowest unoccupied molecular orbital & LUMO \\
\hline \multirow{3}{*}{$\begin{array}{l}\text { Chemical } \\
\text { properties }\end{array}$} & Partition Coefficient & $\log P$ \\
\hline & Mass & M \\
\hline & Molecule volume & $\mathrm{V}$ \\
\hline \multirow{6}{*}{$\begin{array}{l}\text { Quantum } \\
\text { chemical } \\
\text { descriptors }\end{array}$} & Difference between LUMO and HOMO & $\mathrm{E}_{\mathrm{GAP}}$ \\
\hline & Hardness $[\eta=1 / 2(\mathrm{HOMO}+\mathrm{LUMO})]$ & $\mathrm{H}$ \\
\hline & Softness $(S=1 / \eta)$ & $\mathrm{S}$ \\
\hline & $\begin{array}{l}\text { Electro negativity }[\chi=-1 / 2 \text { (HOMO- } \\
\text { LUMO)] }\end{array}$ & $\mathrm{X}$ \\
\hline & El electro philicity $\left(\omega=\chi^{2} / 2 \eta\right)$ & $\Omega$ \\
\hline & Mullikenl charge & $\mathrm{MC}$ \\
\hline \multirow{3}{*}{$\begin{array}{l}\text { Chemical } \\
\text { properties }\end{array}$} & Molecule surface area & SA \\
\hline & Hydration energy & $\mathrm{HE}$ \\
\hline & Refractivity & REF \\
\hline
\end{tabular}

TABLE-3

CORRELATION COEFFICIENT EXISTING BETWEEN THE VARIABLES USED IN DIFFERENT MLR AND GA-MLR EQUATIONS

\begin{tabular}{cccccc}
\hline & MC4 & MC17 & NPA12 & EP4 & $\begin{array}{c}\text { Exact } \\
\text { polaribi- } \\
\text { zibility }\end{array}$ \\
\hline MC4 & 1 & 0 & 0 & 0 & 0 \\
MC17 & -0.39316 & 1 & 0 & 0 & 0 \\
NPA12 & 0.29398 & -0.03346 & 1 & 0 & 0 \\
EP4 & 0.180981 & 0.34743 & 0.653347 & 1 & 0 \\
$\begin{array}{c}\text { Exact } \\
\text { polaribizibility }\end{array}$ & 0.044223 & -0.22517 & -0.22909 & -0.5967 & 1 \\
\hline
\end{tabular}

In a quantitative structure-activity relationship study, generally, the quality of a model is expressed by its fitting ability and prediction ability and of these the prediction ability is the more important. With the selected descriptors, we have built a linear model using the set data and the following equation was obtained:

$\mathbf{p I C}_{\mathbf{5 0}}=42.9988( \pm 33.56039)+0.389185( \pm 0.139432)$ MC4 + $0.28915( \pm 0.090227)$ MC17-0.9568 ( \pm 0.408303$)$ $\mathrm{NPA} 12+2.529824( \pm 2.171152) \mathrm{EP} 4+0.003992( \pm 0.001102)$ exact polarizibility:

$\mathrm{N}_{\text {train }}=29 \mathrm{~N}_{\text {test }}=7 \mathrm{R}_{\text {train }}^{2}=0.82 \mathrm{R}_{\text {test }}^{2}=0.74 \mathrm{R}_{\text {adj }}^{2}=0.54 \mathrm{~F}_{\text {train }}=$

$7.59 \mathrm{~F}_{\text {test }}=0.57 \mathrm{Q}_{\mathrm{LOO}}^{2}=0.70 \mathrm{Q}_{\mathrm{LGO}}^{2}=0.74 \mathrm{Q}_{\text {BоOT }}^{2}=0.60$

The better regression models were selected on the basis of the higher $\mathrm{R}, \mathrm{F}$ value (a statistic of assessing the overall significance) and the lower SEE. Cross validation procedure [leave-one-out $\left(\mathrm{Q}_{\text {LOO }}^{2}\right)$ and leave five-out $\left(\mathrm{Q}_{\text {LFO }}^{2}\right]^{31}$ was applied to measure the predictive capabilities of the models by using Matlab 6.5 program. The built model was used to predict the test set data and the prediction results are given in Table-1. As can be seen from Table-1, the calculated values for the $\mathrm{pIC}_{50}$ are in good agreement with those of the experimental values. The predicted values for $\mathrm{pIC}_{50}$ for the compounds in the training and test sets using eqn. 1 were plotted against the experimental $\mathrm{pIC}_{50}$ values in Fig. 1. A plot of the residual for the predicted values of $\mathrm{pIC}_{50}$ for both the training and test sets against the 
experimental $\mathrm{pIC}_{50}$ values are shown in Fig. 2. As can be seen the model did not show any proportional and systematic error, because the propagation of the residuals on both sides of zero are random.

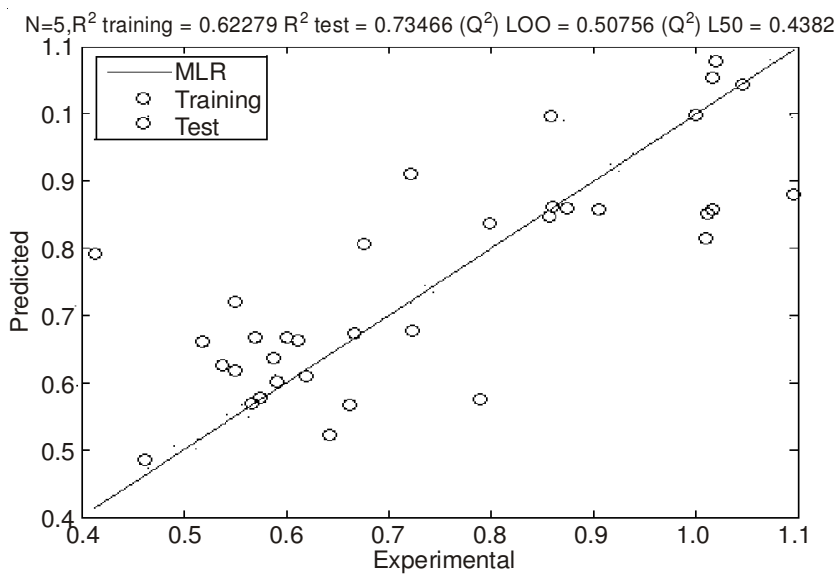

Fig. 1. Plot of predicted activity against the corresponding experimental activity for the cross-validation

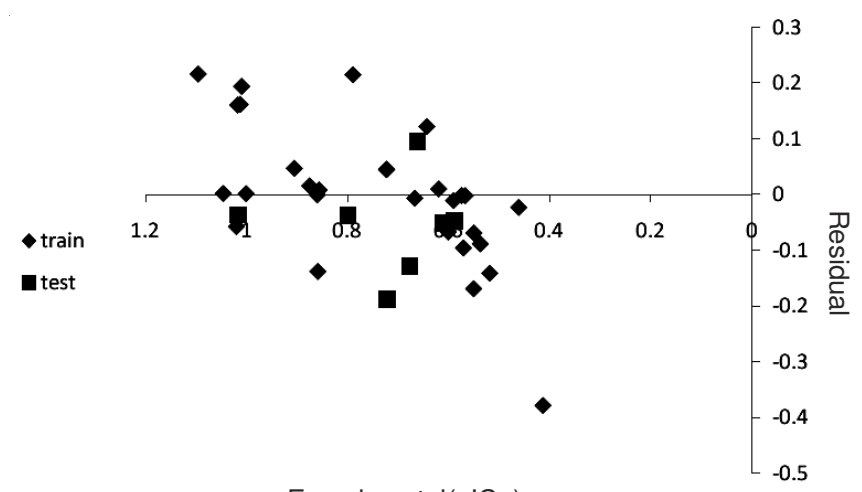

Experimental $\left(\mathrm{plC}_{50}\right)$

Fig. 2. Residual versus the experimental $\mathrm{pIC}_{50}$ by GA-MLR

In order to assess the robustness of the model, the Yrandomization test was applied in this study ${ }^{32,33}$. The dependent variable vector $\left(\mathrm{pIC}_{50}\right)$ was randomly shuffled and a new quantitative structure-activity relationship model developed using the original independent variable matrix. The new quantitative structure-activity relationship models (after several repetitions) would be expected to have low $\mathrm{R}^{2}$ and $\mathrm{Q}^{2}$ Loo values (Table-4). If the opposite happens then an acceptable quantitative structureactivity relationship model cannot be obtained for the specific modelling method and data.

\begin{tabular}{ccc}
\hline \multicolumn{3}{c}{ TABLE-4 } \\
$\mathrm{R}^{2}{ }_{\text {train }} \begin{array}{c}\text { AND } \mathrm{Q}_{\text {Loo }}^{2} \text { VALUES AFTER SEVERAL } \\
\text { Y-RANDOMIZATION TESTS }\end{array}$ \\
\hline \multicolumn{3}{c}{$\mathrm{R}^{2}{ }_{\text {train }}$} \\
\hline Iteration & 0.003298 & $\mathrm{Q}_{\text {LOO }}^{2}$ \\
\hline 1 & 0.003475 & 0.228912 \\
3 & 0.033076 & 0.149282 \\
4 & 0.187993 & 0.256127 \\
5 & 0.026977 & 0.059104 \\
6 & 0.030128 & 0.228785 \\
7 & 0.086354 & 0.25766 \\
8 & 0.047476 & 0.316356 \\
9 & 0.026229 & 0.305111 \\
10 & 0.303182 & 0.11979 \\
& & 0.585411 \\
\hline
\end{tabular}

Applicability domain: The Williams plot (Fig. 3), the plot of the standardized residuals versus the leverage, was exploited to visualise the applicability domain ${ }^{34}$. The leverage indicates a compound's distance from the centroid of $\mathrm{X}$. The leverage of a compound in the original variable space is defined as $^{35}$ :

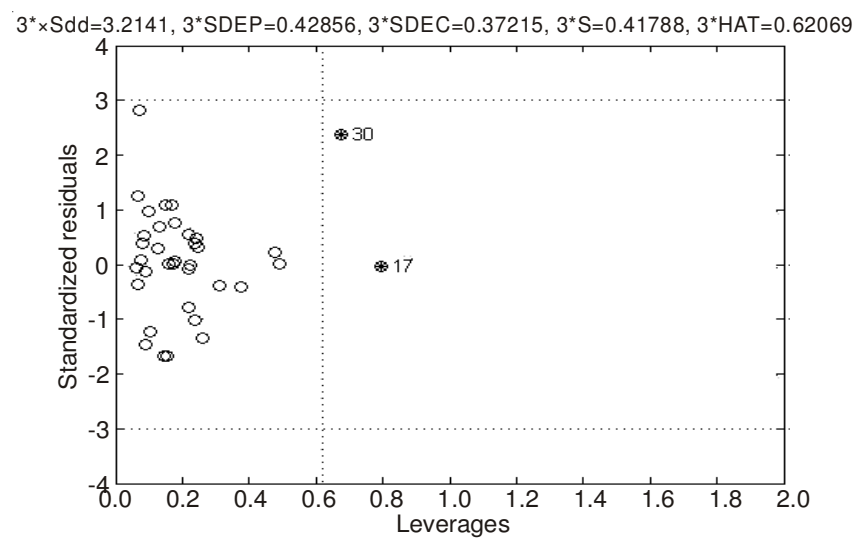

Fig. 3. William plot of the GA-MLR model

\section{Conclusion}

In this study, a quantitative structure-activity relationship study of 36 molecules showing L-type calcium channel blocking activity was performed based on the theoretical molecular descriptors calculated by the Gaussian 98 software. The built model was assessed comprehensively (internal and external validation) and all the validations indicated that the quantitative structure-activity relationship model built was robust and satisfactory and that the selected descriptors could account for the structural features responsible for the 1, 4 dihydropyridiness. The quantitative structure-activity relationship model developed in this study can provide a useful tool to predict the activity of new compounds and also to design new compounds with high activity.

\section{ACKNOWLEDGEMENTS}

Financial support of this project by Research Council of Mashhad University of Medical Sciences is acknowledged.

\section{REFERENCES}

1. L.L. Isom and K.S. De Jongh, Neuron., 12, 1183 (1994).

2. M.S. Kim, T. Morii, L.X. Sun, K. Imoto and Y. Mori, FEBS Lett., 318, 8 (1993).

3. W.A. Catterall and J. Striessnig, Trends Pharmacol. Sci., 13, 256 (1992).

4. A.S. Fleckenstein, Ann. Rev. Pharmacol. Toxicol., 17, 149 (1977).

5. R.A. Coburn, M. Wierzba, M.J. Suto, A.J. Solo, A.M. Triggle and D.J. Triggle, J. Med. Chem., 31, 2103 (1988).

6. M. Ramesh, W.C. Matowe, M.R. Akula, D. Vo, L. Dagnino, M.C. LiKwong-Ken, M.W. Wolowyk and E.E. Knaus, J. Med. Chem., 41, 509 (1998).

7. N. Iqbal, M.R. Akula, D. Vo, W.C. Matowe, C.A. McEwen, M.W. Wolowyk and E.E. Knaus, J. Med. Chem., 41, 1827 (1998).

8. D. Vo, W.C. Matowe, M. Ramesh, N. Iqbal, M.W. Wolowyk, S.E. Howlett and E.E. Knaus, J. Med. Chem., 38, 2851 (1995).

9. A. Shafiee, A.R. Dehpour, F. Hadizadeh and M. Azimi, Pharm. Acta Helv., 73, 9 (1998).

10. F. Hadizadeh, M.F. Hassanabad, B.B. Golabadi and M. Mohammadi, Bol. Chim. Farm., 144, 1 (2005).

11. F.I.M. Hadizadeh, F. Mohammadpour, P. Mihanparast and M. Seifi, Saudi Pharm. J., 2, 170 (2009). 
12. M. Iwanami, T. Shibanuma, M. Fujimoto, R. Kawai, K. Tamazawa, T. Takenaka, K. Takahashi and M. Murakami, Chem. Pharm. Bull., 27, 1426 (1979).

13. C. Hansch, P.G. Sammes, J.B. Taylor, P.D. Kennewell, J.C. Emmett and C.A. Ramsden, Comprehensive Medicinal Chemistry: The Rational Design, Mechanistic Study and Therapeutic Application of Chemical Compounds: Pergamon Press (1990).

14. B. Hemmateenejad, R. Miri, M.A. Safarpour, M. Khoshneviszadeh and N. Edraki, Theochemistry, 717, 139 (2005).

15. C. Hansch, A. Kurup, R. Garg and H. Gao, Chem. Rev., 101, 619 (2001)

16. Q.-L. Wei, Sh.-Sh. Zhang, J. Gao, W.-H. Li, L.-Zh. Xua and Zh.-G. Yub, Bioorg. Med. Chem., 14, 7146 (2006).

17. A. Kumar, B. Narasimhanb and D. Kuma, Bioorg. Med. Chem., 15, 4113 (2007)

18. S. Putta, J. Eksterowicz, C. Lemmen and R. Stanton, J. Chem. Inf. Comput. Sci., 43, 1623 (2003).

19. R. Todeschini, V. Consonni, Handbook of Molecular Descriptors, Wiley-VCH, Weinheim (2000).

20. D. Horvath and B. Mao, OSAR Comb. Sci., 22, 498 (2003).

21. R. Carbo-Dorca, L. Amat, E. Besaqlu, X. Girones and D. Robert, J. Mol. Struct. (Theochem.), 504, 181 (2000).

22. M. Karelson, V.S. Lobanov and A.R. Katritzky, Chem. Rev., 96, 1027 (1996).

23. P. Thanikaivelan, V. Subramanian, J.R. Rao and B.U. Nair, Chem. Phys. Lett., 323, 59 (2000).

24. M.J. Frisch, G.W. Trucks, H.B. Schlegel, G.E. Scuseria, M.A. Robb, J.R. Cheeseman, V.G. Zakrzewski, J.A. Montgomery Jr., R.E. Stratmann, J.C. Burant, S. Dapprich, J.M. Millam, A.D. Daniels, K.N. Kudin, M.C Strain, O. Farkas, J. Tomasi, V. Barone, M. Cossi, R. Cammi, B. Mennucci, C. Pomelli, C. Adamo, S. Clifford, J. Ochterski, G.A. Petersson, P.Y. Ayala,
Q. Cui, K. Morokuma, D.K. Malick, A.D. Rabuck, K. Raghavachari, J.B. Foresman, J. Cioslowski, J.V. Ortiz, A.G. Baboul, B.B. Stefanov, G. Liu, A. Liashenko, P. Piskorz, I. Komaromi, R. Gomperts, R.L. Martin, D.J. Fox, T. Keith, M.A. Al-Laham, C.Y.Peng, A. Nanayakkara, C. Gonzalez, M. Challacombe, P.M.W. Gill, B. Johnson, W. Chen, M.W. Wong, J.L. Andres, C. Gonzalez, M. Head-Gordon, E.S. Replogle, J.A. Pople, Gaussian 98, Revision A.7, Gaussian Inc., Pittsburgh PA (1998).

25. A.D. Becke, J. Chem. Phys., 98, 5648 (1993).

26. C. Lee, W. Yang and R.G. Parr, Phys. Rev. B, 37, 785 (1988).

27. R.S. Mulliken, J. Chem. Phys., 23, 1833 (1955).

28. A.E. Reed and F. Weinhold, J. Chem. Phys., 78, 4066 (1983).

29. I.N. Levine, Quantum Chemistry, Prentice Hall and Rovide Publisher Location and Block, edn. 5, pp. 508-509 (2000).

30. ACD/Labs, Advanced Chemistry Development Inc., Toronto, Canada (1995).

31. R.D. Clark, D.G. Sprous and J.M. Leonard, in eds.: H.-D. HPltje and W. Sipplin, Rational Approaches to Drug Design, Porous Science, SA, pp. 475-485 (2001).

32. A. Tropsha, P. Gramatica and V.K. Gombar, QSAR Comb. Sci., 22, 69 (2003).

33. S. Riahi, M.R. Ganjali, P. Norouzi and F. Jafari, Sens. Actuators B, 132, 13 (2008).

34. OECD, Guidance Document on the Validation of (Quantitative) StructureActivity Relationships [(Q)SAR] Models. Paris: Organization for Economic Co-Operation and Development, pp. 256-278 (2007).

35. T.I. Netzeva, A.P. Worth, T. Aldenberg, R. Benigni, M.T.D. Cronin, P. Gramatica, J.S. Jaworska, S. Kahn, G. Klopman, C.A. Marchant, G. Myatt, N. Nikolova-Jeliazkova, G.Y. Patlewicz, R. Perkins, D.W. Roberts, T.W. Schultz, D.T. Stanto, J.J.M. van de Sandt, W. Tong, G. Veith, and C. Yang, ATLA-Altern. Lab. Anim., 33, 155 (2005). 